\title{
TRACES OF TRAUMA IN ESTONIAN WOMEN'S LIFE NARRATIVES OF WORLD WAR II
}

\author{
Maarja Hollo \\ Senior Research Fellow \\ Estonian Cultural History Archives \\ Estonian Literary Museum, Estonia \\ Email: maarja.hollo@kirmus.ee
}

\begin{abstract}
The article focuses on the autobiographical life narratives of two Estonian women, Maire Polashek and Aire Kolbre Salmre, who fled from Estonia to Germany in 1944, during the Great Escape to the West, and thence to third states later on, as well as Elin Toona Gottschalk's memoir, all of which include descriptions of traumatic experiences or allusions to such experiences. Thematically, the stories and memories involve recollections of events that occurred during World War II, before the narrators and their families escaped from their homeland, their journey to Germany, and local life as displaced persons in one or several refugee camps or at a local German's household. Several of the women use excerpts from their parents' memories or diaries in their narratives, thereby seeking support for their own reminiscences. The purpose of the article is to explore the traces of war trauma that can be found in the autobiographical life narratives of Estonian women who as children reached Germany among the confusion of World War II, as well as the ways in which the traumatic experiences are mediated in the narratives.
\end{abstract}

Keywords: autobiographical life narratives, Estonian refugees, war trauma, World War II

\section{WORLD WAR II AND TRAUMA}

Trauma has been defined as the psychological impact sufferings have on individuals who are either temporarily or permanently unable to attribute meaning to their traumatic experience. Owing to its retroactive nature, trauma can be seen as a temporal disruption: the traumatic event cannot be acknowledged, comprehended or recognized immediately after it occurred, while at the same time, the memories of that event cannot be retrieved as something that belongs to the past; trauma can manifest itself in various symptoms, such as intrusive thoughts, recurring, involuntary flashbacks, hallucinations or dreams. This is 
why sufferers of post-traumatic stress disorder (PTSD) are "trapped in a state of ongoing temporal disruption and fixed traumatic identity" (Jensen 2019: 78). The purpose of the article is to explore the traces of war trauma in the autobiographical life narratives and memories of three Estonian women who as children fled from Estonia to Germany in the autumn of 1944 and wrote down their stories more than half a century after the events described in the texts occurred.

Peter Leese and Jason Crouthamel note that in the history of studying trauma, more attention has been paid to men's stories, primarily because there is a wealth of sources on men's immediate war experiences (Leese \& Crouthamel 2016: 3). In the context of historical trauma studies, World War I and the Holocaust have been studied the most, but Leese and Crouthamel consider that World War II was a formative moment in the social, cultural, and political history of trauma, since World War II offers researchers more historical sources of various types as well as opportunities of comparing the military, medical, and social aspects of the event (ibid.: 7). Although the concept of trauma and the related theoretical framework have been increasingly used in studying wars and catastrophes in the last two decades of the twentieth century, the concept has received modest attention in researching World War II in Estonia. For example, trauma is mentioned only in two articles in Soldiers of Memory: World War II and Its Aftermath in Estonian Post-Soviet Life Stories (2011), a collection of life stories of eight Estonian men who participated in World War II and the treatments thereof: in Aili Aarelaid-Tart's article "The Estonian-Minded Person in Soviet Reality: Double Mental Standards in Ailo Ehamaa's Life History"1 (Aarelaid-Tart 2011) and in Tiina Kirss' article "When is the War Over? YloVesse Velvelt's Life Story and Surviving the 'Czech Hell”' (Kirss 2011).

However, the concept of trauma has been employed in studies that focus on autobiographical writing, including diaries, of Estonian women, which cover the topic of Soviet repressions (Kurvet-Käosaar 2013, 2014). For example, in her article on the deportation stories of Estonian and Latvian women, Leena Kurvet-Käosaar states that although the stories are about experiences that are traumatic in nature, they are rarely treated in a manner that would allow to clearly outline the signs of trauma contained in the stories, which is why it would be problematic to employ a corresponding theoretical approach (KurvetKäosaar 2012, 2013). Kurvet-Käosaar considers that the authors made a conscious choice of avoiding narrating their sufferings so as not to conflict with the national narrative, presenting themselves "as successful survivors" (KurvetKäosaar 2013: 131), while Eneken Laanes brings out another reason why the language of trauma as a certain memorial form ${ }^{2}$ has not become widespread in remembering repressions in Estonian memory culture - the domination of 
a different memorial form shaped by Estonian history and culture and characterised by a way of depiction underlining unwavering bravery and resilience, which originates from the fact that the life narratives of individuals and the collection thereof are related to the context of restoring national history starting from the 1990s (Laanes 2017: 248).

What, however, is characteristic of this memorial form that we can trace on the basis of the autobiographical life narratives and life stories of refugees who fled to Germany from Estonia in 1944? Undoubtedly, most of them contain experiences that can be identified as traumatic, yet are the experiences communicated with the language of trauma? Tiina Kirss, who has studied the life stories and biographical interviews of Estonian refugees, has been rather cautious in engaging with the concept of trauma and even distanced herself from it. In the collection Rändlindude pesad: Eestlaste elulood võõrsil (The Nests of Migrating Birds: Life Stories of Estonians Abroad) (2006) which contains the life stories of Estonians who fled to Germany or Sweden during World War II and travelled on to third countries from there, Kirss claims that in the case of Estonians' displacement stories, applying trauma as a template of interpretation by a researcher is not as important as understanding the formation of the "social memory" of the escape stories, i.e., the timeline when the escape stories began to be published, how and when the stories were told and how the escape experience was psychologically processed (Kirss 2006: 617). As it is not the intention of this article to answer the question how escape stories become a part of the refugees' memory culture and politics of memory, but to identify the ways and means of communicating experiences that can be interpreted as traumatic, I shall focus on the stories where the narrator either seems to allude to or directly talks of her psychological suffering and pain caused by the events of World War II.

The psychological responses of people who were forced to leave their homeland due to war, political unrest, persecution or natural disaster, i.e. refugees, to events they have survived have been characterized with the concept of double crisis (Rumbaut 2005), existential trauma (Bennich-Björkman 2016), and trauma of displacement (Hron 2018). To be exact, I use the term of war trauma in this article, as the traumatic experiences communicated in the autobiographical life narratives and memories to be discussed here are not solely connected to displacement and adjustment issues in a new country of residence but also to war events that happened before the narrators escaped their homeland.

In the throes of World War II, approximately 75,000-80,000 Estonians fled their homes and journeyed mainly to Finland, Sweden, and Germany. About 40,000 Estonians reached Germany, approximately 1,000 of them as Reichsarbeitsdienst (the Reich Labour Service) recruits. The service lasted for a year 
and was a prerequisite for furthering one's education (Hinrikus 2009: 113). The greatest wave of escape occurred in the autumn of 1944. The last refugees arrived in Germany via the sea route or through Latvia, Lithuania, and Poland in mid-October. The Third Reich offered refugees "hard work, tiring drives, poor food and bare wooden bunk beds in dirty barracks. ... In the critical hours of leaving their homeland and on the road, each individual Estonian and family suffered shocking dramas, the depth of which is completely understood only by those who were among the refugees themselves back then" (Kool 1999: 8). Thus, underlining the psychological impact of escaping, Ferdinand Kool describes the situation of Estonian refugees who arrived in Germany in his book titled DP kroonika: Eesti pagulased Saksamaal 1944-1951 (DP Chronicles: Estonian Refugees in Germany 1944-1951), which is among the most important sources of the daily life of Estonian refugees in local camps.

Some refugees found a place of residence and a job independently when they reached Germany, but most Estonian refugees preferred to convene at camps a trend that took more massive proportions starting from the summer of 1945 . After World War II Germany was divided into four zones: American, British, French, and Soviet zone of occupation. The greatest number of Estonian refugees was located at the camps of the American zone. Estonians, Latvians, and Lithuanians mostly lived together at the camps, some also housed members of other nations. The residents quickly started organizing their cultural and educational life: kindergartens and schools began to operate, and the Baltic University was opened in 1946. At first, it was not difficult to find a place in the camps: one just needed to register with a committee or at a United Nations Relief and Rehabilitation Administration (UNRRA) institution (ibid.: 422). However, in late 1945 the selection process became more rigorous and, instead of committees and UNRRA officials, displaced persons' (DP) centres started deciding over who would get a place in the camps (ibid.). The camps were first administered by the Supreme Headquarters Allied Expeditionary Forces (SHAEF) and then by international refugee organisations: Intergovernmental Committee on Refugees (IGCR) and the United Nations Relief and Rehabilitation Administration, as well as military authorities (Kumer-Haukanõmm 2009: 20). Camp life began to die out in the summer of 1947, when a new authority called the International Refugee Organization (IRO) was established to solve the refugee issue and started to send refugees to third countries (ibid.: 20).

Maire Polashek, Aire Kolbre Salmre, and Elin Toona Gottschalk also reached Germany with their families in the autumn of 1944, all of them being children at the time when the described events took place. In their autobiographical life narratives about pre-war Estonia, escaping from Estonia, and daily life in war-torn Germany, they also recollect events that had a traumatic impact on 
them as children. In the following section, I explore how each of them communicates their traumatic experiences in their narratives, paying special attention to episodes where the narrators describe, explain, and attribute meaning to such experiences.

\section{MAIRE POLASHEK'S AUTOBIOGRAPHICAL LIFE NARRATIVES}

Maire Polashek was born in 1933 in Tallinn, Estonia. In September 1944, she fled to Germany with her father, mother, and younger sister. Three of Maire's autobiographical life narratives, which have been published in a collection of expatriate Estonians' memories titled Mälutunglad (Torches of Memory), ${ }^{3}$ are undoubtedly exceptional in the context of Estonian women's World War II memories, primarily because of the detailed description of events, figurative language use, and the nuanced communication of the narrator's emotions. In her narratives, Maire recollects war events, the escape from Estonia and refugee life from the vantage point of a child, who was six years old when World War II started. As a child, war was an unexpected, scary and traumatic experience for her, leaving a deep mark on the rest of her life as a refugee.

Rutt Hinrikus has noted the following about Estonians' memories of World War II:

The memories of all authors born in the period from 1905 to 1940 are dominated by war events or life changes caused by the war. All the autobiographical writings about this period have the common aspect of personally experienced or witnessed violence. (Hinrikus 2009: 112)

It is, of course, different how a child experiences violence as opposed to an adult, which, in turn, influences the ways in which people recollect such experiences as grown-ups. For the generations born before World War II, who fled Estonia in 1944, war meant traumas that they started to recollect in detail and work through decades after the events occurred.

Maire Polashek wrote down her autobiographical life narratives more than 50 years after World War II broke out. Her first story titled "Kirju liblikas ja saatuslikud suvekuud: Põgenemine läbi Saksa-Vene rindeliini 1941. aasta juulis" (A Motley Butterfly and Fateful Summer Months: Escape through the German-Russian Line in July 1941) was published in 2002 and, according to Maire, was instigated by the wish to "communicate the truth as I remember and experienced it" (Polashek 2002: 423). Maire's narrative is framed by Estonians' belief that the first butterfly one sees in spring predicts what the summer will be like. In the spring of 1941, the first butterfly Maire saw was a multi-coloured 
one and she says that the summer of that war year turned out motley both for her and for all Estonians. The historical context of Maire's narrative is Russians' retreat and Germans' arrival in Estonia. The Republic of Estonia was incorporated into the Soviet Union on 17 June 1940, when the latter took over all Estonian institutions and bodies of power. The people who were considered dangerous by the new authorities were arrested, imprisoned or executed. It is estimated that Estonia lost approximately 94,000 people during the first Soviet occupation. The situation changed in the summer of 1941: the front shifted to Soviet Russia and the German army arrived in Estonia. Maire begins her first autobiographical life narrative about these times as follows:

In the last days of June in 1941, our carefree games in the yard of our home at Nõmme suddenly came to an end. On this fateful day, a youngish man stepped inside the gate, whispered something in my mother's ear in a low voice and hurried off. The beautiful northern summer days were reaching their apex when we three together with our dog Ginni said goodbye to our home in the afternoon sun a little while later. ... The messenger had insisted that we leave home immediately so as not to fall victim to those who were using violence against our people. This dark fear was, indeed, justified, because witnesses said they came to take us away that very same night as well as the following one. (Polashek 2002: 424)

Maire, her mother and sister fled to the countryside, to the farm of Maire's maternal grandmother. The four brothers of Maire's mother were hiding away from the war in the forest; the youngest of them, whom Maire remembers with great affection in her narratives, was seven years older than her and still a young boy herding the family's cattle.

Maire's grandmother had a big farm with enough work for the entire family. The children were tasked with keeping watch and warning the adults about approaching Russian soldiers. This was also Maire's responsibility. However, as the Germans approached, the Russians grew more violent. In her narrative, Maire extremely dramatically describes how the Russians unexpectedly surrounded her grandmother's farm one day:

My father, who was usually in hiding in the forest, had come home to eat and was sitting at the table. When he saw they had surrounded the house and he had no escape route, he climbed into the large bread oven that was still emanating heat after baking. Grandmother closed the mouth of the oven from the outside. The feared guests were not in a joking mood. They started to question poor grandmother and tried to coerce her to provide information about her sons by threats. ... Straw and haystacks 
were pierced with bayonets. They only failed to search the oven where father was sweating and barely gasping for air in danger of suffocating. (Polashek 2002: 425)

In describing what happened to her father, Maire bases her narrative on the memories of either her father or her grandmother, as she herself as a child could not have been the direct witness of these events, yet the level of detail with which Maire communicates other family members' memories is remarkable.

As the front drew closer, Maire with her mother and younger sister needed to escape to the forest in fear of violence. People from other nearby farms also found shelter in the forest: Maire says that in the end, the group of refugees consisted of thirty-two people, four of whom were children. As the summer was warm, they slept in barns. The children were tired of fleeing, pestered by gnats and troubled by hunger. As the sense of threat increased, adult refugees decided to cross the Russian-German line. The situation grew tenser because they were far away from home in unfamiliar surroundings. Maire recollects:

I have a clear memory picture of crossing this formidable section, how every one of us needed to cross it alone. Only mother and I ran across it together, holding hands tight. ... A dangerous journey lay ahead. We wandered around like lost children. The pits of bog pools shimmered in the moonlight and yarn from my knee-highs got stuck in the thicket of marsh bushes, scratching my shins until they were bloody. Only rags were left of my dress. (Polashek 2002: 427)

Soon, the refugees reached the location of a large camp where a number of other refugees and forest brethren (partisans) had been killed a few days ago. It is noteworthy that Maire describes the scene only in a couple of sentences:

The monster of destruction was staring at us from all sides. On a higher hilltop, there was a large cauldron with discarded dishes, overturned tables, benches, boots, items of clothing here and there. And on the hillside lay those who had paid the ultimate price for freedom. (ibid.)

For Maire as a child, seeing such a large number of people killed must have been her first-time encounter with death during the war. It seems that it was easier for her to mediate this extremely traumatic memory which she very clearly remembers but does not go into via a scene which can be interpreted as an image of ultimate horror. Gadi Benezer, who studied trauma signals in the biographical interviews of the Jews who escaped from Ethiopia in the years 1977-1985, has identified the narrator reporting an 'image of ultimate horror' as one of these signals. This image is "an event or a scene which serves 
as a symbol of a series of traumata experienced or witnessed" (Benezer 2004: 34). The function of the image of ultimate horror in Maire's narrative is to help moving on with the narrative without creating a longer disruption in the process of recollection.

Maire's next narrative, "Muudatuste tuultes" (In the Winds of Change) was published in 2003. In that narrative, Maire recollects how she and her family fled from Estonia in the autumn of 1944, and what their refugee life was like in Germany during World War II. As in Maire's first narrative about the war years in Estonia, her second autobiographical life narrative also contains detailed descriptions of the escape journey and life as a refugee among strangers. This narrative contains images which yet again seem to signify the narrator's wish to abstain from delving into some of the traumatic episodes she has had in her life and recollecting them in detail. Thus, it can be said that the images in her stories function as signs of silence or symbols that allow remembering the unbearable and writing about it.

A characteristic example is an episode that focuses on the events that occurred immediately before Maire's family left Estonia. On the day of the escape, her father drove his family on a motorcycle to the port where German vessels were moored. As all the family members could not ride the motorcycle all at once, father decided to take Maire to the port first. They were supposed to sail away on board of one of the three German warships there. When Maire reached the ship and her father had left, it was announced that the ship would leave the port already in twenty minutes' time. Maire understood that she could not stay on the ship, as otherwise she would never have seen her father, mother or sister again. She decisively grabbed her bundles, left the ship, and worriedly waited for the rest of her family at the port: "Thousands of lives were torn apart. We were suffocating under the burden of loss. We were as if short of breath. I breathed deeply and swallowed the lump in my throat. But where were my parents?" (Polashek 2003: 190) Suddenly, she hears the roar of her father's motorcycle, which fills her with inexplicable happiness. Maire ends this episode with the sentence: "A candle had been lit on the windowsill of our pains" (Polashek 2003: 190), where the candle as the symbol of hope also signifies her fear of losing her family as a child.

After Maire's mother negotiated in vain for their passage in another vessel, an unknown man offered their family the opportunity to board the ship RO-24. As in all her stories, Maire interprets this unexpected turn of events as a miracle: "A miracle of a kind had been born. Although we had no idea about the journey awaiting us in Germany, we were grateful for the kind offer" (Polashek 2003: 191). Although relieved, Maire is also tremendously sad to have to leave her homeland, which she expresses only more than half a century later, when 
recalling the event: "I wanted to cry. I wanted to wash out all the anxiety, pain, and despair accumulated in me - to wail helplessly with despair. But I could not" (ibid.: 191).

The motif of a miracle is repeated in Maire's narrative even when she describes the bombing of German ships by Russian military aircraft and the multitude of human casualties:

The catastrophe was, indeed, horrible. Thrice more lives were lost on the Moero compared to the Titanic. As the number of victims was so great, all of them were transported to a single field where those who survived could identify them. Row upon row, they were laid to rest in simple wooden boxes - both big and small, identified and unidentified - side by side in foreign soil; their fate forever unknown to their near and dear. ... For those who stood by the graves, the sky only showed its dark side, the stars had grown dim there as well. Countless lives were also lost in storms on the way to Finland and Sweden due to the motors of small fishing vessels breaking down and the boats being overloaded. Some refugees were caught by the Russian navy and were lost in air raids. Over us, however, hovered invisible wings, and the sincere prayers of our dear ones who were left behind accompanied all of us on the way. It was truly a miracle to be alive. (Polashek 2003: 192)

Maire's narration does not reveal whether she herself was at the burial of the dead, yet she considers it important to incorporate knowledge of the tragic fate of refugees who were not so lucky as to reach a new country alive into her narration of her family's escape abroad. By commemorating others, Maire underlines the miraculous escape of herself and her family, which she as a religious person associates with the power of prayer.

Maire's narrative continues with a description of refugee life in Germany. Life in wartime Germany is draining for refugees, especially children, as there is little food, nowhere to wash, and one is in constant danger of falling victim to an air raid. Yet again, the motif of miracle is repeated in Maire's narrative:

We had barely gone to sleep when the air raid sirens began howling and we had to trudge to the bunkers through the blacked-out city. Some nights were entirely sleepless when we nodded off in the shelter. ... Now, every day of survival seemed like a miracle. In my mature age of eleven, quickly growing old, I was quite aware of the worth of life. Only one wish remained - to get one more day of life, no matter how troublesome it would be. (Polashek 2003: 193) 
To avoid constant travelling that was exhausting both for the children and parents, Maire's parents decided to take the family to the small town of Murnau in the south of Germany. War refugees were not welcome anywhere, but Maire recollects how the locals treated them with sympathy and were helpful.

Maire continues with her memories of refugee life in Germany in her next story titled "Põgenikena Murnaus Lõuna-Baieris Saksamaal" (Refugees at Murnau, South Bavaria, Germany), which was published in 2004. Maire explains that for refugees, acquiring food was still the most important problem, but they also constantly feared allied air raids. In addition to Maire's personal memories, this narrative contains those of her father, mother, and sister, which Maire as a skilled narrator smoothly incorporates into her story. After the war ended, DPs began to be gathered in camps starting from July 1945. Maire's family also had to leave Murnau. Maire and her family travelled to Hamburg, which was in the British zone. Maire recollects:

As the Hamburg airfield was a long way out of the city, we had to take the train into town. I still remember this drive since we had arrived at a land of ruins. We saw no intact building during this journey. Amidst this terrible destruction, a few little lights shone only from cellar windows. These city districts were like endless burial mounds of ruins. (Polashek 2004: 283)

Maire uses the images of the land of ruins and endless graves to summarize the tragic of war and its scope that she had to witness as a child but which seems to be difficult for her to recall even many years later.

To receive help and support from the UNRRA, a refugee needed to have DP status. Maire notes that the Germans "were forced to cope on their own, which is why many starved, especially in the large destroyed cities" (ibid.). Since Maire's father managed to get a Swedish visa in the autumn of 1945, the family travelled from Hamburg to Malmö in December that year. Maire's family remained in Sweden until November 1950 when they relocated to Toronto, Canada.

\section{THE LIFE STORY OF AIRE KOLBRE SALMRE}

Like Maire Polashek, Aire Kolbre Salmre was born in Tallinn, into the family of a military official, an officer of the Republic of Estonia. When the war broke out in 1939, Aire was three, while her sister Kaare was a year old. Aire's 15-page life story ${ }^{4}$ that she sent as an entry to the collection campaign Eesti Vabariik 100: Minu elu ja armastus (The Republic of Estonia 100: My Life and Love), was published in the first volume of the collection Minu elu ja armastus: Eesti rahva elulood (My Life and Love: The Life Stories of Estonian People) and starts 
with a memory picture of how her mother was packing suitcases to escape from Estonia, hoping to fit a couple of photo albums in the bag. Aire's father did not approve of the plan and said: "There is no point in taking these heavy albums with us, we will be back soon, as the world will not let this injustice stand" (Kolbre Salmre 2018: 272). This sense of the temporary deeply characteristic of refugee life, and the underlying hope to return to one's homeland soon contained in Aire's memory picture would accompany Aire's family for a long time. This sense of the temporary was felt the most keenly in Germany, where Aire's family escaped in 1944.

In Aire's life story, there are two clearly distinctive temporalities that the narrator juxtaposes: times before the war that are associated with beautiful childhood memories of "Estonian Christmases, our christenings, Kadriorg and the swans, the elementary school of the Tallinn Teachers' Seminar, Tallinn Drama Theatre, Tallinn Zoo, the central hospital where mother worked and my sister and I were born, the snowy Estonian winters, etc." (Kolbre Salmre 2018: 273), and World War II, which "brought pain and created disorder in the household of peace-loving Estonians" (ibid.). With great nostalgia, Aire describes desserts - jellies, cakes, and pies - the taste of which is especially etched in her mind, and childhood Christmases that are associated with the light of real candles in her memories. Aire places her memory pictures of Christmases, as well as other memories described in her life story into the context of the times when she wrote the memories down, adding:

We have not experienced the wondrous gleam of my childhood's Christmas candles here, abroad. They do not use real candles in America, since the spruces sold here are often brought from afar, where they are cut down in the autumn, and the threat of fire forces one to use electric lights. My childhood Christmases have remained in my heart. (ibid.: 273)

In relation to the war, Aire's life story clearly outlines a child's viewpoint of the events: although the bomb raids and escape engender enormous fear in Aire, so that both she and her sister learn to pray from their mother, Aire admits that the war events sometimes even seemed fascinating for children and brought excitement to their lives. Out of the events preceding the escape, Aire recollects the 9 March bomb raid on Tallinn in detail in her story:

In between the bombing, we went outside. It was night-time and it was winter, but it was light and warm outside. People came out of their houses and started extinguishing burning buildings with pails of sand and water. Five-year-old Kaare and seven-year-old Aire brought their toy buckets, filled them with sand and went to put out flames. No one said that the children should get out of the way! The interlude did not last long as 
the Russian planes returned and continued to destroy Tallinn. (Kolbre Salmre 2018: 275)

This memory picture can be interpreted as a traumatic memory for two reasons. Firstly, it is conspicuous how Aire's narrative shifts from first-person plural to third person when she describes her and her sister fearlessly taking action amidst the chaos of war. The manner of talking about oneself in the third person has also been used by Elin Toona in her autobiography Ella (2008) in recollecting her childhood, not unlike other authors, e.g., Jenny Diski in her autobiography Skating to Antarctica (1997), where she looks back to traumatic childhood events (see Douglas 2010: 125). Secondly, it is important in the case of this memory picture how Aire associates it with the present, i.e., the time of writing, assuring how the things she lived through in the past still affect her current life: "Even now, when there is a lightning storm and thunder rumbles outside, it reminds me of the bombing. The war left its marks even on children who had to live through it" (ibid.: 275).

After Tallinn is bombed, Aire's mother decides to leave the capital with the children and move to Viljandi County, where Aire's godmother lives with her family. There, Aire meets Ingrian children, who had the same affiliations as their parents, Ingrian people brought to Estonia by the Germans - they were waiting for Russian victory. The Ingrian children scare Aire and other local children with stories of revenge, and their fear for the Russians grows even more: "The Ingrian children said that the Russians would soon arrive at Karksi-Nuia, take our toys and cut our heads off!" (ibid.: 276) The children are also scared by the fighter aircraft that constantly fly over the fields, their main playground.

As the war progressed, Aire's family decided to flee to Sweden from Estonia. First, they planned to go by boat, but as the Germans requisitioned locals' vessels to stop them from fleeing to Finland and Sweden, Aire's family could not get to Sweden. Thanks to her father's military connections, the family managed to board the German ship Peter Wessel that left the island of Saaremaa on 28 September 1944 and reached Gotenhafen the next day. Aire recollects that a huge crowd was left behind on the coast of Saaremaa, who descended into panic when their ship left, shouting: "They are escaping, what will happen to us, the Russians are coming?" (Kolbre Salmre 2017 [2015]: 192). Aire adds that this painful memory picture of the people left behind is "etched" into her memory.

In Germany, refugees had to live in barracks where the living conditions were extremely poor, "unnatural", as Aire writes (ibid.: 277), which is why many children and adults fell ill. Aire and her sister Kaare were infected with chickenpox and then measles, but Aire recollects that, despite all these hardships, barrack life seemed novel and interesting for the children. In Germany, 
Aire had to attend a German school, which seemed scary and alienating. Aire remembers that on the first day at the strange school, Estonian children had to stand in front of the class after she peed her pants:

The German children started to laugh. ... A German boy said something, which made the rest of the class laugh again. The female teacher then proceeded to slap the boy. The Germans were accustomed to slapping, which I experienced first-hand, when we lived in the Blomberg refugee camp after the war. One time, I was roller skating on the street right by where we lived,... when a German passed me and gave me a slap in the face. (Kolbre Salmre 2018: 278)

Being subjected to physical violence as a child is explained by Aire in retrospect by the Germans' widespread anger towards war refugees, who were a burden to Germany.

In the spring of 1945, allied bomb raids on Germany grew more frequent. Another sign of war trauma in Aire's life story is the memory of how she got a deep scar on her left leg when a bomb raid began:

I have a permanent souvenir of that time: A deep scar sustained when I collided with a sharp stair edge during one such urgent transit. I lost a lot of blood but fortunately the wound healed to only leave its permanent mark of those times. (Kolbre Salmre 2017 [2015]: 195)

The memory of this wound testifies, above all, to the child's fear of bombing and death; however, in hindsight, it symbolizes for Aire the entire war-time, which left a permanent mark on her. In the same spring, Aire contracted pneumonia, but as there were no doctors, mother treated her "to the best of her knowledge" and Aire recovered from the illness. Aire has incorporated her mother's memories of fleeing the Russians in her narrative, as she recollects widespread panic among the Estonians of falling in the clutches of the Russians. Aire's family succeeded in reaching the Americans and her mother gave an American soldier a silver spoon as a sign of gratitude. After a month of travelling in Germany, in early June 1945, Aire's family reached Blomberg, which was in the British zone. "The small town of Blomberg together with the good and bad memories it created became our home for the following four years," says Aire in her narrative, without explaining what were the bad memories associated with camp life (Kolbre Salmre 2018: 281). In the autumn of 1949, Aire's family succeeded in relocating to America, where they settled near New York. 


\section{ELIN TOONA GOTTSCHALK'S INTO EXILE: A LIFE STORY OF WAR AND PEACE}

The ways in which traumatic experiences are mediated in Maire Polashek's autobiographical life narratives and Aire Kolbre Salmre's life story are notably different from how Elin Toona shares her experiences with readers in her book of memories Into Exile: A Life Story of War and Peace (published in 2013, Estonian translation in 2017). Elin Toona is an author who writes both in Estonian and English. She has published four novels and four autobiographical works, including autobiography Ella, dedicated to her grandmother Ella Enno (published in 2008), and the biography of her grandfather, poet Ernst Enno, Rõõm teeb taeva taga tuld (Joy Sparks Fires Behind the Sky, 2000).

Like Polashek and Kolbre Salmre, Toona recollects her childhood in prewar Estonia, years of World War II, fleeing Estonia in 1944, and life as a war refugee in Germany in her book of memories, with the addition of the description of her youth and early adulthood in England. Rutt Hinrikus calls Toona a writer who "tells her story throughout her creative works, each time in greater detail, more precisely, finding increasingly more opportunities to do so" (Hinrikus 2016: 191). Among other autobiographical life stories of Estonian women, which communicate war traumas, Toona's book primarily stands out because of its richness of details, scope, and the author's direct manner of speaking about deep suffering, the traumatic dimension of which is underlined by the author's estimations and explanations. For example, in the epilogue of the book, the author admits: "There are incidents that I cannot frame with words and frames that I cannot fill adequately with facts but the scenes are as vivid now as they were at the time they happened" (Toona Gottschalk 2013: 355). Thus, there are often no words to describe events that have a traumatic impact, but similarly to events that can be written about, their influence does not diminish in time, still affecting the author and directing how she shares one or another memory with the reader. This is confirmed by the memories of the same events in Toona's life story (published in the collection Eesti rahva elulood II: Sajandi sada elulugu kahes osas (The Life Stories of Estonian People: One Hundred Life Stories of the Century. Vol. II) in 2000), in the autobiography Ella (2008), and in the book titled Into Exile: A Life Story of War and Peace (2013), which differ by the manner of communication.

It is claimed that the process of coping with trauma is closely related to the reconstruction of collective and individual identity as well as the compensation of loss (Bartov 1999: 25). Toona's memoir, where the author binds her individual identity with collective, national identity, when she places certain episodes of 
her narrative in the context of so-called history at large, quoting the works of various historians and politicians, as well as newspapers and other contemporary sources, can be seen as such a reconstruction. Upon reading Toona's book, one can sense her wish of making peace with her father, whom she got to know only as an adult and via letters, her mother, with whom she had difficult relations since childhood, as well as her past, the brightest moments of which were connected to memories about her grandmother, who was there for her in all situations - loving, kind, and supportive.

Toona recollects her childhood, the years of World War II, fleeing her homeland, life in Germany and later in England in her life story as well as in the autobiography Ella (2008). Compared to the life story and the memories narrated in Ella, the retrospect presented in the book titled Into Exile: A Life Story of War and Peace is more detailed and, when comparing the two texts, it seems that with this volume the author is trying to achieve something that might be labelled as emotional precision. In her memoir, Toona writes about the events that are regarded as so-called great history, placing "small battles" that occurred at the same time in the family, between her and parents, in the background, although they were more traumatic for the child than the ongoing great war. She had no mental or physical connection with her mother, whom she calls the Snow Queen in the book, and who left Toona with her grandmother when she was still a small child; Toona's father abandoned the family already before the Great Escape in the autumn of 1944. In this situation, Toona's mother did not find it feasible to stay in Estonia and decided to flee to Sweden with her daughter and mother. The Toona family reached Saaremaa by ferry and her mother succeeded in securing a boat there. The moments before the escape were marked by uncertainty and were therefore extremely tense, but Toona, being a child, did not understand her mother's despair; it simply engendered frantic fear in her: "Mother's crying upset me. Every time I had seen her cry, something terrible had been about to happen. I was getting ready to jump or hide as she had instructed" (Toona Gottschalk 2013: 38). It was no less terrifying to float, soaking wet, on the stormy Baltic Sea, in a boat full of refugees and about to overturn any minute. The refugee boat was discovered by a Polish cargo ship whose captain promised to take everyone aboard. Toona's mother started to climb the rope ladder to the ship, asking for her mother and child to be rescued as well. However, Toona as a child did not understand that and thought her mother intended to leave her again: "I squeezed my eyes shut again. ... When I opened my eyes, Mother was climbing up the side of the ship. She was leaving us, going back to Tallinn, to return to a "life of her own." I could not blame her" (Toona Gottschalk 2013: 40). Toona descended into even greater panic when 
she saw her grandmother also disappear on the deck of the ship: "I had been prepared for anything but for Grandmother to abandon me. I became hysterical" (ibid.: 40). Toona describes the same episode in her life story, emphasizing the persistence of this memory: "Grandmother went away alone, and left me in the boat at first. I thought both of them were leaving me and I screamed for dear life. ... I did not understand a thing, yet memories of this have stayed with me for my entire life" (Toona 2000: 248).

Finally, Toona got on the ship as well, but her sufferings did not come to an end with this, since Russian planes were constantly bombing vessels on the Baltic Sea. As it was the child's greatest fear to lose her family and remain alone, she decided not to close her eyes for the entire time on the ship. In the following days, the Polish cargo ship rescued many other war refugees, two of whom are fleetingly recollected by Toona in the book. These were two women, one of whom had lost her palms, while the other was carrying a dead child on her back.

Another woman, crawling on her hands and knees, was dripping wet and confused about which way to go. She had a baby tied to the back of her neck with a belt crossed over her chest. The baby's head was lolling back and forth with her every movement. When she tried to stand I stepped forward to tell her that her baby was dead, but Grandmother noticed my intention and grabbed me by my coat. She forced me back down the stairs. (Toona Gottschalk 2013: 43)

The traumatic nature of this episode is revealed in the dialogue that follows between Toona and her grandmother, which provides an emotional frame for the entire episode. Toona as a child was traumatized not so much by the fact that she had to witness the tragic situation of the woman who had lost her child but was unaware of it, but by the fact that she wished to notify the mother of the death of her child. ${ }^{5}$ Toona's grandmother, however, quickly noticed this and forbade her to do it - in other words, Toona could not do what she considered best in this situation, which is why this episode is associated with a persistent sense of injustice for her.

Toona, her mother and grandmother arrived at Danzig on 25 September 1944. From there, they travelled by train to Berlin, which had been destroyed by bombing, and where they could not stay for long, as the air raids grew increasingly frequent. Toona only passingly mentions their Berlin days in her life story, but provides a longer description of their painful experiences in the autobiography: 
Air raids were always scary, but at least there was a roof over one's head in the shelters, cellars and subway tunnels, there were just walls in the ruins. Being in open air during an air raid turned out to be a terrifying experience. ... Bombs fell from the sky and the earth shook from explosions. The air was full of smoke and white chalk that blew hot, like from the mouth of a furnace. They lay on top of each other and waited for death to come. (Toona 2008: 48)

This memory picture brings forth the attitude to death during war-time: death becomes a natural part of people's everyday lives, something that each one of them has to consider at any moment.

On 4 October of the same year, Toona, her mother and grandmother reached Hausberge, where at the railway station they learnt by chance that the wife of the local pastor was offering accommodation for war refugees in her house. Although the allied air raids continued, Toona, her mother and grandmother now had a relatively safe place to stay. The bombing had a devastating effect on the child's psyche: she begun to suffer from nightmares, which she learnt to control by blinking fast, shaking her head and shouting: "Wake up!" (Toona Gottschalk 2013: 70). Toona recollects she could not sleep without her grandmother, yet even her presence did not save Toona from the ever-repeating nightmares, one of which she describes in the book as follows:

But the worst dream of all was of flying like an angel, then suddenly losing altitude over a city of smouldering ruins and landing on the pavement, where people in grey shrouds were crawling on their hands and knees in mud. The mud became thicker, slimier, and deeper until it rose above my head and I drowned. (ibid.: 70)

Daily challenges were added to the nightly sufferings, as Toona started to attend a local school with Nazi sympathies, where she had to bear humiliation and bullying from both the teacher and the students. She was saved from this daily torture by an allied plane that bombed the schoolhouse one day. "My worst memories are connected to Hausberge," says Toona in her life story, leaving her statement unexplained (Toona 2000: 248).

In the spring of 1945, allied forces, first the Americans, then the British, reached Hausberge, which was in the British zone. Toona evaluated this turn of events by her mother's reaction that she followed closely as a child. When she saw joy and relief in her mother's eyes, Toona understood that the entire situation had suddenly changed. Yet, her mother's joy that also infected Toona, soon turned to sadness by irony of fate due to the inexplicable behaviour of her mother, over the causes of which Toona pondered until she became an adult. 
An incident that occurred with Toona became the impulse behind her mother's anger and desire to punish: the then 7-year-old Toona was raped by a British soldier who was observing Toona, her friend Ursula, and other children's game of hide-and-seek. The soldier asked for permission to join the children's play, but it quickly became clear that he was only interested in satisfying his desire when he interfered in the game. In light of the knowledge she had gathered up till then, Toona interpreted the soldier's attack as him wanting to pee, since she had seen many times how men "urinated anywhere they wanted to" (Toona Gottschalk 2013: 93). ${ }^{6}$ After the rape, Toona fled to her grandmother without understanding much of what had happened. Toona describes the rape scene from the point of view of a child who has not yet discovered sexuality and is not aware of the role it has in adults' lives. A few days after the rape, mother came to Toona, but not to comfort the child, but to punish her with a savage beating until Toona's grandmother stopped her. Upon reading Toona's narrative closely, one may conclude that for her, it was not that much the rape that was traumatizing for her, but her mother's behaviour after the incident. Toona recollects that she did not understand why her mother was punishing her but it convinced her conclusively that "she would never, never love" her (ibid.: 95).

It became clear by early May that Germany had lost the war. The refugees began to be gathered to camps advertised in UNRRA publications. Toona, her mother and grandmother went to live at the Meerbeck camp established near Hannover. Ferdinand Kool says it was "an ordinary German village consisting of five farms and a few craftsmen's buildings. The British accused the residents of the village of being accomplices in murdering a British airman. The village was emptied of Germans and a repatriation camp was founded there. Later on, the village buildings were handed over to a DP camp. The first group of Estonians, 27 people, arrived there on 28 June 1945 from the regions of Salzwedel and Ackern, which were in the east zone" (Kool 1999: 351). Toona also writes of the murder in her book:

Untilled fields on either side of the road supported the story that Mother had translated about the villagers having been evicted for killing the English pilot. People like us were now living in their houses. I bet they were not happy about it. (Toona Gottschalk 2013: 101)

Thus, awareness of their undesired presence intrinsically accompanies the refugee status, be the refugee an adult or a child.

When they arrived at the camp, it turned out that the room that was allocated to Toona, her mother and grandmother was even smaller than the one where they had lived in Hausberge because a single person was allowed a maximum 
of 3-5 $\mathrm{m}^{2}$ at the camp (Kool 1999: 426). Food was still a problem, as the rations were too small to dispel the constant hunger. Later on, uncle Paul, the younger brother of Toona's grandfather, who had arrived in Germany before the end of the war from the French Foreign Legion, helped them to acquire food. To alleviate the lack of food, people grew pigs at the camp against local laws and went to steal potatoes from the Germans' fields at night. "The Germans were angry but could do nothing," reminisces Toona in her autobiography Ella (Toona 2008: 63). Poor washing facilities resulted in fleas and bedbugs that pestered children and adults alike, as well as the constant feeling of cold since firewood was difficult to come by in camp life.

In the summer of 1946, the British government announced the intention of recruiting 1,000 single women from the camps of the British zone to come and work at English hospitals, sanatoriums, and treatment facilities as nurses, cleaners, and laundry workers. The campaign was called Baltic Swans, and 700 Estonian women reached England as a result (Kool 1999: 687). It was popular among the Estonians of the British zone, as people wanted to get away from the camps no matter how and wished to earn money to travel elsewhere later on (ibid.: 694). Kool notes that England suited "all who wanted to leave Germany but remain in Europe and wait for the liberation of their homeland" (ibid.). Toona says people preferred England owing to its cultural reputation:

Many believed they were going to "Hardy country." This vision included thatched cottages, village greens, duck ponds, and, of course, London. What they got instead was William Blake's "Satanic Mills," the filth and squalor of the Industrial North. (Toona Gottschalk 2013: 131)

Toona's mother Liki arrived in England in 1947, having signed a five-year employment contract. She started work in a women's hospital in Leeds, where she was assigned manual labour: scrubbing and polishing the floors, dusting, emptying chamber pots and washing laundry (Toona 2008: 58). Since the 'swans' could not take their families to their new country of residence, Toona and her grandmother remained at the Meerbeck camp for another year. Toona describes arriving at Leeds as an experience that did not shock only her and her grandmother but all foreign workers:

What we were seeing for the first time and what shocked every foreign worker who had signed up to work in Great Britain was the reality of this other England - no demi-paradise, but a mucky, money-making machine of the Industrial Revolution. (Toona Gottschalk 2013: 137) 


\section{CONCLUSION}

Studying traumatic experiences is complicated, on the one hand, due to the fact that such experiences "can damage episodic memory processes, fragmenting recall of detail and removing the event from semantic context and therefore meaning" (Jensen 2019: 97), which hinders the creation of a coherent narrative or prevents the person who suffers trauma from speaking about his/her experiences at all. ${ }^{7} \mathrm{On}$ the other hand, articulating traumatic experiences may be prevented by circumstances independent of the survivor of trauma: by the memorial form dominating the culture at a certain point in time, as claimed by Eneken Laanes in her article on camp and deportation memories (Laanes 2017), cultural norms ${ }^{8}$ that do not favour revealing aspects of one's personal life (Jaago 2018) or the lack of suitable cultural models as examples via which one could communicate one's experiences.

Historical trauma is rooted in historical experience, which is why both have been associated with the term of recollection as opposed to historical consciousness or memory related to historical taboos (Van den Braembussche 1999: 171-172). Philosopher of history Antoon Van den Braembussche, who has studied the issue of silencing the past and the ways in which communities try to cope with the past that is difficult to handle, claims that silencing the past is not a question of simple ideological or psychological embarrassment but is closely related to the ways in which we perceive time as such, in which we "conceptualize and try to manage it in our historical narratives" (ibid.: 172). Since Van den Braembussche considers that today, historical consciousness is governed by the politics of time, which transforms the past so that it resembles a fiction of the present, the result is "extreme reversibility" (ibid.: 191). In such a situation, it is recollection that offers a way out. It can reattribute to events their irreversibility and reinstate their divergent times, which cannot be communicated by a linear or cyclical model of time. Through recollection, the temporality of trauma, the events of which are always unexpected and undesired, can counter the silencing of the past, which the politics of time is continually legitimizing.

The autobiographical life narratives and the book of memories discussed in this article are valuable historical source materials on the impact of World War II since they allow the reader to "re-experience the affective and cognitive inside of a historical moment" (Jensen Wallach 2006: 228). The authors, three women who fled to Germany from Estonia as children during the Great Escape of 1944, communicate in their narratives what they saw and experienced during World War II, each in her own way. The shared topoi of the narratives are 
recollections of events that occurred before World War II and during the escape from Estonia, the journey to Germany and local life as a displaced person in one or several refugee camps or at a local German's household. All the narratives bear traces of war trauma that is present in the texts either explicitly, with the addition of the narrator's comments and explanations, or implicitly, if the narrator prefers to use figurative language in mediating the traumatic experiences. This way of relating traumatic experiences is characteristic of Maire Polashek's autobiographical life narratives, where one can sense that the narrator does not want to describe the traumatic events in detail so as to avoid reliving them. In her narratives, Polashek commemorates Estonian refugees who died during World War II, with the purpose of recognizing collective suffering. Although Elin Toona Gottschalk articulates her traumatic experiences with neutral language in her book titled Into Exile: A Life Story of War and Peace, she strives for detail and emotional precision, relating the experiences from the point of view of a child who does not fully understand what is happening to her. Traumatic episodes that are primarily related to difficult relations with Toona's parents, mainly her mother, but also the shocks of the war in her memories, are placed in the context of historians' writings as well as several other contemporary sources, thereby tying her, her mother's and grandmother's story to the stories of other people who left their homeland as refugees because of World War II. One of the dedications of the book also directly refers to the intention of telling the story of "us, the refugees of World War II": "I dedicate this book to my mother and grandmother, Liki Toona and Ella Enno, and to all the World War II refugees who were unable to return home after the war and became lifelong exiles". Aire Kolbre Salmre places the events she recollected in her life story in the context of the time when she wrote them down, evaluating the past from the vantage point of the present. She employs this strategy also in describing traumatic episodes of the past, thereby emphasizing the traumatic nature of the experiences she narrated. The connections of trauma and nostalgia are also prominent in Kolbre Salmre's life story: the loss of one's homeland primarily manifests in the narrator's yearning for certain familial events and small pleasures important for a child, such as childhood sweets and the glow of Christmas lights.

When studying autobiographical life narratives that mediate traumatic experiences, one can gain a better understanding of and therefore acknowledge the psychological suffering of the people whose voice has not been heard in society for various reasons, often independent of themselves. However, for those who go through trauma, the voicing of their suffering publicly has another function. Meg Jensen claims that "autobiographical narratives that draw upon traumatic 
experience can enact a search for recognition, justice, and meaning, that may, through exposure and detachment, lead finally to acceptance and even healing" (Jensen 2019: 19). The Estonian women's autobiographical life narratives of their childhood that coincided with World War II, discussed in this article, show that the traces of certain experiences persist in memory and are retraced through narration to clarify one's past and thereby alleviate suffering, which, in turn, substantially affects how the person perceives and interprets his/her life at the time of writing.

\section{ACKNOWLEDGEMENTS}

The article was supported by the research grant of the Estonian Literary Museum EKM 8-2/20/1 and by the Centre of Excellence in Estonian Studies (TK 145) through the European Regional Development Fund.

\section{NOTES}

1 In this article Aarelaid-Tart uses the term 'cultural trauma', which she defines as a "violent value invasion; sudden, repressive application of 'alien' axiological scales that rapidly oppose age-old traditions" (Aarelaid-Tart 2011: 288).

2 The language of trauma has been defined as transnational memorial form which enables the psychological effects of traumatic experiences to come forth (see Laanes 2017).

3 In 2000, an autobiographical writing group started meeting under the lead of Tiina Kirss at Tartu College in Toronto. Both Maire Polashek and her younger sister Virge took part in it. Altogether six collections of autobiographical life writings have been compiled of the works authored by the members of the group (2002, 2003, 2004, 2008, 2011, and 2013), the latest of which is in English.

4 Aire Kolbre Salmre has also written her life story in English, titled "And So It Happened" (Kolbre Salmre 2017), which was published in the collection titled From Here Began the Journey to Far Off Lands: Hats off to Estonian War Parents, compiled by Mai Maddisson.

5 It is interesting that in her autobiography Ella Toona avoids recounting this memory: "They climbed the stairs together and reached the deck just when the crew had pulled a netful of people out of the water. They were laid on the deck like fish. Elin saw something terrible there and Ella steered her down the stairs again" (Toona 2008: $45)$. 
6 Toona also depicts the rape in her autobiography Ella, but in relatively few words: "Ursula and Elin had intended to hide together, but the soldier dragged Elin into the bushes. Ursula was afraid to go with them but had remained close (like mother had told her to) and watched how the solider and Elin struggled under the bush" (Toona 2008: 56).

7 For example, the compiler of the collection When the Noise Had Ended: Geislingen's DP Children Remember (2009), Mai Maddisson discusses in the afterword why so few of the Geislingen children sent memories of their escape from Estonia and the time they lived at the camp: "Whatever has become of the nine-hundred-plus of the Geislingen youngsters we did not hear from? Some would have died. Where those deaths very premature? How many found their journey too onerous, burdened by both memories and the difficulties of integration into new lands? Are the ones who made contact those who dared touch the past? Maybe they had better resources to do so; maybe they have never had to bury their past" (Maddisson 2009: 211).

8 In her article "Trauma ja elulood" (Trauma and Life Stories), Tiiu Jaago states the following: "The two analysed life stories were narrated in the late 1990s, early 2000s. They do not represent the idiomatic language of trauma in general, yet present certain characteristics that could be searched for in the idiomatic language of trauma employed during the decades at the turn of the century. One of them is restrained narration. The narrator mentions but will not discuss things she has suffered in personal life. This is substantiated with two arguments. Firstly, narration does not spare the narrator of reliving the emotions she had in the past. The narrator does not want to experience it. Secondly, the choice to remain silent is based on cultural norms - you do not reveal all that has happened to you to a stranger" (Jaago 2018: 133-134).

\section{REFERENCES}

Aarelaid-Tart, Aili 2011. The Estonian-Minded Person in Soviet Reality: Double Mental Standards in Ailo Ehamaa's Life History. In: Ene Kõresaar (ed.) Soldiers of Memory: World War II and Its Aftermath in Estonian Post-Soviet Life Stories. Amsterdam \& New York: Rodopi, pp. 279-296.

Bartov, Omer 1999. Trauma and Absence. In: Helmut Peitsch \& Charles Burdett \& Claire Gorrara (eds.) European Memories of the Second World War. New York \& Oxford: Berghahn Books, pp. 258-271.

Benezer, Gadi 2004. Trauma Signals in Life Stories. In: Kim Lacy Rogers \& Selma Leydesdorff \& Graham Dawson (eds.) Trauma: Life Stories of Survivors. New Brunswick \& London: Transaction Publishers, pp. 29-44.

Bennich-Björkman, Li 2016. Life Interrupted But Mended: Trauma and the Remembering Self among Estonian and Bosnian Émigrés. In: Kirsti Jõesalu \& Anu Kannike (eds.) Cultural Patterns and Life Stories. Tallinn: TLU Press, pp. 183-210.

Douglas, Kate 2010. Contesting Childhood: Autobiography, Trauma, and Memory. New Brunswick \& New Jersey \& London: Rutgers University Press. 
Hinrikus, Rutt 2009. Naised ja sõda eesti naiste mälestustes ja kirjanduses. [Women and War in the Memoirs of Estonian Women and in Estonian Literature.] In: Jaan Ross \& Arvo Krikmann (eds.) Teadusmõte Eestis V: Humanitaarteadused. [Research in Estonia: The Humanities.] Tallinn: Eesti Teaduste Akadeemia, pp. 107-118. Available at https://www.digar.ee/arhiiv/et/raamatud/14973, last accessed on 4 March 2020.

Hinrikus, Rutt 2016. Elin Toona loomingu autobiograafilisus. [The Autobiographical in Elin Toona's Work.] In: Leena Kurvet-Käosaar \& Marin Laak (eds.) Adressaadi dünaamika ja kirjanduse pingeväljad. [Dynamics of the Addressee and the Fields of Connectivity in Estonian Literature.] Tartu: Tartu Ülikooli Kirjastus, pp. 190-201.

Hron, Madelaine 2018. The Trauma of Displacement. In: J. Roger Kurtz (ed.) Trauma and Literature. Cambridge: Cambridge University Press, pp. 284-298. https:// doi.org/10.1017/9781316817155.021.

Jaago, Tiiu 2018. Trauma ja elulood. [Trauma and Life Stories.] Mäetagused, Vol. 71, pp. 111-142. https://doi.org/10.7592/MT2018.71.jaago2.

Jensen, Meg 2019. The Art and Science of Trauma and the Autobiographical: Negotiated Truths. London: Palgrave Macmillan.

Jensen Wallach, Jennifer 2006. Building a Bridge of Words: The Literary Autobiography as Historical Source Material. Biography, Vol. 29, No. 3, pp. 446-461. https://doi. org/10.1353/bio.2006.0063.

Kirss, Tiina 2006. Põgenemisteekonnad ja põgenemislood. [Exile Journeys, Exile Stories.] In: Maarja Hollo \& Rutt Hinrikus \& Külli Trummal (eds.), Tiina Kirss (comp.) Rändlindude pesad: Eestlaste elulood võorsil. [The Nests of Migrating Birds: Life Stories of Estonians Abroad.] Tartu: Eesti Kirjandusmuuseum, pp. 611-646.

Kirss, Tiina Ann 2011. When is the War Over? Ylo-Vesse Velvelt's Life Story and Surviving the 'Czech Hell'. In: Ene Kõresaar (ed.) Soldiers of Memory: World War II and Its Aftermath in Estonian Post-Soviet Life Stories. Amsterdam \& New York: Rodopi, pp. 365-383.

Kolbre Salmre, Aire 2017 [2015]. And So It Happened. In: Mai Maddisson (ed.) From Here Began the Journey to Far Off Lands: Hats off to Estonian War Parents. Melbourne: Brolga Publishing, pp. 189-198.

Kolbre Salmre, Aire 2018. Elulugu. [Life Story.] In: Rutt Hinrikus \& Tiina Ann Kirss \& Ülle Kaart (eds.) Minu elu ja armastus: Eesti rahva elulood. 1. köide. [My Life and Love: The Life Stories of Estonian People. Vol. 1.] Tallinn: Tänapäev, pp. 272-287.

Kool, Ferdinand 1999. DP kroonika: Eesti pagulased Saksamaal 1944-1951. [DP Chronicle: Estonian Refugees in Germany 1944-1951.] Lakewood, New Jersey: Eesti Arhiiv Ühendriikides.

Kumer-Haukanõmm, Kaja 2009. Eestlaste põgenemine Saksamaale. [The Flight of Estonians to Germany.] In: Terje Hallik \& Kristi Kukk \& Janet Laidla (eds.) Eestlaste põgenemine Lä̈̈nde Teise maailmasõja ajal: Artiklid ja elulood. [The Flight of Estonians to the West during the Second World War: Articles and Life Stories.] Tartu: Korp! Filiae Patriae, pp. 13-53. 
Kurvet-Käosaar, Leena 2012. Vulnerable Scriptings: Approaching Hurtfulness of the Repressions of the Stalinist Regime in the Life-Writings of Baltic Women. In: Fatima Festic (ed.) Gender and Trauma: Interdisciplinary Dialogues. Newcastle upon Tyne: Cambridge Scholars Publishing, pp. 89-111.

Kurvet-Käosaar, Leena 2013. Voicing Trauma in the Deportation Narratives of Baltic Women. In: Gabriele Rippl \& Philipp Schweighauser \& Tiina Kirss \& Margit Sutrop \& Therese Steffen (eds.) Haunted Narratives: Life Writing in an Age of Trauma. Toronto \& Buffalo \&, London: University of Toronto Press, pp. 129-151.

Kurvet-Käosaar, Leena 2014. Creating a Habitable Everyday in Estonian Women's Diaries of the Repressions of the Stalinist Regime. In: Magda Stroińska \& Vikki Cecchetto \& Kate Szymanski (eds.) The Unspeakable: Narratives of Trauma. Peter Lang Verlag, pp. 141-156.

Laanes, Eneken 2017. Trauma keelde tõlgitud: Kultuurideülesed mäluvormid eesti laagri- ja küüditamismälestustes. [Translated into the Language of Trauma: Transcultural Patterns of Memory Observed in Estonian Memoirs of the Gulag and Deportation.] Keel ja Kirjandus, Vol. 4, pp. 241-257. Available at http://kjk. eki.ee/ee/issues/2017/4/910, last accessed on 5 March 2020.

Leese, Peter \& Crouthamel, Jason 2016. Introduction. In: Peter Leese \& Jason Crouthamel (eds.) Traumatic Memories of the Second World War and After. London: Palgrave Macmillan, pp. 1-16.

Maddisson, Mai 2009. Reflection: The Magnificent Oak. In: Mai Maddisson (comp.), Priit Vesilind (ed.) When the Noise Had Ended: Geislingen's DP Children Remember. Woodsville, NH: Lakeshore Press, pp. 208-213.

Polashek, Maire 2002. Kirju liblikas ja saatuslikud suvekuud: Põgenemine läbi SaksaVene rindeliini 1941. a. juulis. [A Motley Butterfly and Fateful Summer Months: Escape through the German-Russian Line in July 1941.] In: Tiina Kirss (comp.) Mälutunglad: kogumik kirjutisi Tartu College’i elulugude kirjutajate rühmast 2000-2002. [Torches of Memory.] Toronto: Tartu College, pp. 424-429.

Polashek, Maire 2003. Muudatuste tuultes. [In the Winds of Change.] In: Tiina Kirss (comp. \& ed.) Mälutunglad II: kogumik kirjutisi Tartu College'i elulugude kirjutajate rühmast 2002-2003. [Torches of Memory. Vol. II.] Toronto: Tartu College, pp. 189-200.

Polashek, Maire 2004. Põgenikena Murnaus Lõuna-Baieris Saksamaal. [Refugees at Murnau, South Bavaria, Germany.] In: Tiina Kirss (comp. \& ed.) Mälutunglad III: kogumik kirjutisi Tartu College’i elulugude kirjutajate rühmast 2003-2004. [Torches of Memory. Vol. III.] Toronto: Tartu College, pp. 276-286.

Rumbaut, Rubén G. 2005. The One-and-a-Half Generation: Crisis, Commitment, and Identity. In: Peter I. Rose (ed.) The Dispossessed: An Anatomy of Exile. Amherst \& Boston: University of Massachusetts Press, pp. 331-355.

Toona Gottschalk, Elin 2013. Into Exile: A Life Story of War and Peace. Woodsville, NH: Lakeshore Press.

Toona, Elin 2000. Elulugu. [Life Story.] In: Rutt Hinrikus (comp.) Eesti rahva elulood II: Sajandi sada elulugu kahes osas. [The Life Stories of Estonian People: One Hundred Life Stories of the Century. Vol. II.] Tallinn: Tänapäev, pp. 243-255. 
Toona, Elin 2008. Ella. Tallinn: SA Kultuurileht.

Van den Braembussche, Antoon 1999. The Politics of Time: Reflections on Time, Memory and History. In: Anne Ollila (ed.) Historical Perspectives on Memory. Helsinki: Suomen Historiallinen Seura, pp. 171-193.

Maarja Hollo is senior research fellow $(\mathrm{PhD})$ at the Estonian Cultural History Archives at the Estonian Literary Museum, Estonia. Her main fields of interest are the mediation of traumatic experiences in Estonian life writing and the representation of trauma in Estonian exile literature.

maarja.hollo@kirmus.ee 